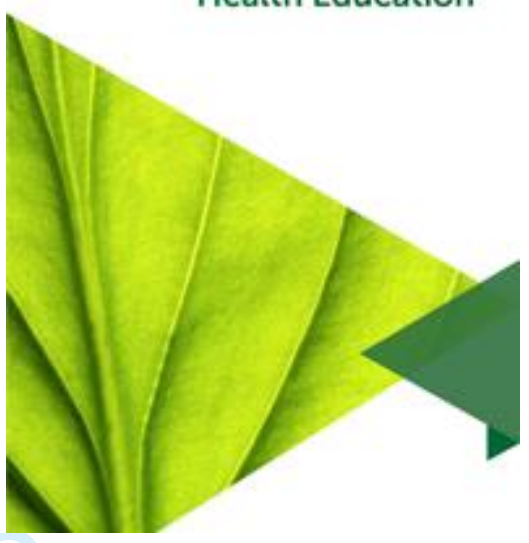

\title{
Health education teachers' historical bodies: Constructing teacher identity and teaching information evaluation
}

\begin{tabular}{|r|l|}
\hline Journal: & Health Education \\
\hline Manuscript ID & HE-10-2020-0096.R1 \\
\hline Manuscript Type: & Original Article \\
\hline Keywords: & Health education, Teaching \\
\hline \multicolumn{3}{r}{} \\
\\
& SCHOLARONE \\
& \\
&
\end{tabular}

Emerald is the publisher of this chapter and permission has been granted for this version to appear here http://urn.fi/urn:nbn:fi-fe202101202192. Emerald does not grant permission for this article to be further copied/distributed or hosted elsewhere without their express permission. 


\title{
Health education teachers' historical bodies: Constructing teacher identity and teaching information evaluation
}

\begin{abstract}
Purpose - This article describes how Finnish health education teachers verbalise and construct their teacher identity based on their lifestyle, subject area, and relationships with their students.

Design/methodology/approach - Narrative interviews were conducted among eight secondary and upper secondary school teachers. Nexus analysis was used to analyse teachers' methods of teaching students' information-seeking, evaluation, and critical thinking skills.

Findings - The teachers' historical bodies - their skills, interests, informationseeking habits, and familiar sources_-impacted the chosen teaching methods. The results indicate that teacher identity is constructed along different paths and is constantly performed and transformed in the classroom through interactions with students.
\end{abstract}

Originality - The study illustrates the reconstruction of teacher identity through interaction in interviews. Teachers act as role models, information gatekeepers, and trustees who guide students to choose credible health information sources.

Keywords Critical thinking, Health education, Historical body, Information evaluation, Nexus analysis, Teacher identity

Paper type Research paper 


\section{Introduction}

Contemporary health information is fragmented and multichannelled. The amount of information available exceeds the human capacity to handle it. In 2020, when COVID19 spread across the world, the Internet was suddenly flooded with information on the disease that was only partially credible and correct. The ability to locate and evaluate contradictory health information critically became more important than ever.

Health education teachers play an essential role in guiding students towards credible information sources on issues related to health and wellbeing. In Finland, health education is a stand-alone and mandatory subject in secondary school aimed at enhancing students' versatile health literacy; that is, seeking, evaluating, producing, and utilising health information (Finnish National Board of Education, 2016; Nygård et al., 2020). Besides theoretical and practical health-related knowledge, desirable learning outcomes in health education include health communication, self-efficacy, critical thinking, and functional literacy (Ormshaw et al., 2013).

At the secondary level, students' information-seeking and evaluation skills are still developing; thus, they tend to rely heavily on their teachers' guidance (Heinström and Sormunen, 2019; Nygård et al., 2020). Moreover, a teacher serves as a trusted person, or trustee, who directs students towards credible information sources (Jessen and Jørgensen, 2012; Nygård et al., 2020). This position is not self-evident but is socially constructed and influenced by, for instance, a trusting relationship between the teacher and students (Nygård et al., 2020), the teacher's content knowledge, and pedagogy in the classroom interaction (Tschannen-Moran and Hoy, 2000). These personal and professional factors represent a teacher's identity (Beijaard and Meijer, 2017), on which they base their teaching practices and ways of encountering students; that is, how they "fulfil the duties of the position" (Gee, 2000). 
This paper focuses on Finnish health education teachers' ways to construct their teacher identity and considers teachers' professional choices, training, and experience when teaching health information-seeking and critical evaluation skills to students.

\subsection{Teacher identity}

Blommaert (2005) defined identity as "who and what you are" (p. 203). However, instead of being stable, identity evolves and alters according to the situation, context, and purpose. Teachers' pasts including their former careers, teacher training, and life experiences, form their way of teaching and how they view it (Ball and Goodson, 1985). Life outside of school also has an impact on teacher's work and thus, on their teacher identity (Ball and Goodson, 1985). In particular, the concept of teacher identity refers to the way in which teachers see and consider themselves as teachers (Mockler, 2011). Teacher identity is continually performed and transformed through classroom interaction by teachers' doings and knowledge (Miller, 2009).

Teacher identity research on pre-service teachers (e.g. Beauchamp and Thomas, 2009; Christensson, 2019) and primary teachers (e.g. McDougall, 2010; Palmér, 2016) has been vibrant for some time. Subject teachers' teacher identity has been of interest in several recent studies (e.g. Anspal et al., 2019; Bukor, 2015; Lutovac and Kaasila, 2019). In research on teacher identity, health education has been studied as an adjunct to other subjects, most commonly physical education and social studies (e.g. Byrne et al., 2018; Pang and Soong, 2016; Sirna et al., 2010; Tinning, 2004). This is because, unlike Finland, other countries do not teach health education as an independent, mandatory subject; it is instead taught as a part of physical education or in a combination of subjects (Kannas et al., 2009). 
Although health education is a stand-alone subject in Finland, teachers usually teach it as a second teaching subject (Kannas et al., 2009). According to Kannas et al., (2009), health education teachers' primary teaching subjects are most often physical education, home economics, and biology. This influences the formation of their teacher identity because most teachers have a particular preference for their subject; the field they have primarily chosen to study is their special interest (Sikes, 1985). In England and Ireland, health education is taught as a part of social and personal education (Byrne et al., 2018). Although the subject is compulsory in Ireland, it can only be studied as a minor subject. Thus, teachers' own specialist subject has a greater influence on their professional identity (Mannix McNamara et al., 2012).

In Australia, health and physical education (HPE) teachers traditionally identify themselves as "doers" and physical activity seekers, with less of an emphasis on health (Tinning, 2004). Puchegger (2018) found that for HPE teachers, the body plays an important role in constructing teacher identity. Furthermore, teachers seem to behave differently during health education lessons compared to physical education lessons. In addition, teacher identity likely depends on teachers' relationships with students and the students' needs; thus, each moment can generate a new performance of identity (Puchegger, 2018).

Teacher identity draws upon subject expertise and pedagogical knowledge, but working environments and interaction maintain the change and the development of teacher identity throughout a teacher's career (Bukor, 2015; Day, 2012; Jourdan et al., 2016). Although teacher identity has been widely studied, in the context of information evaluation, research is still scarce. This area needs to be explored, as teachers are no longer just information mediators but serve as information sources and guides to other credible sources (Nygård et al., 2020). 


\subsection{The aim of the study}

The aim of this study is to examine health education teachers' construction of teacher identities in relation to teaching information seeking and evaluation. The findings of this study will help to broaden our understanding of teachers' roles in guiding students towards credible health information sources and enhancing their critical thinking skills. The following research questions are addressed:

How do health education teachers construct their teacher identity during an interview?

How do the teachers verbalise their role in teaching students to seek and critically evaluate information?

\subsection{Theoretical perspective}

The theoretical perspective of this study emerges from nexus analysis and its concept of historical body. The main objective in nexus analysis is to understand social action and the significance of different mediational means in that action (Scollon and Scollon, 2004). At the center of social action, historical body is intertwined with two other significant elements: discourses in place and interaction order (Scollon and Scollon, 2004). Discourses in place draws attention to aggregates of discourses circulating in material places (Scollon and Scollon, 2004). Interaction order, in turn, means all the social arrangements, by which social relationships are formed in the social action (Scollon and Scollon, 2004). Mediational means (or cultural tools) refer to language and other semiotic or material communicating means that people use in social action (Scollon, 2001). Understanding social action involves understanding the tension between the provided mediational means and their actual use (Jones and Norris, 
2005; Wertsch, 1994). Norris (2004) differentiated actions into lower-level and higher-level actions, of which lower-level actions pointed at the smallest interactional meaning units, such as, single sayings and sentences. Higher-level actions, in turn, consisted of many chained lower-level actions. The focus of this study is on higher-level actions, like teaching and learning, rather than on people, discourses, or technologies, specifically (see Scollon and Scollon, 2004). Teachers' professional choices in information-seeking and evaluation situations may create tension between their practices and desired learning outcomes, which generate a change in their habitual ways of teaching and, thus, their teacher identity (Räisänen and Korkeamäki, 2015).

In this article, teacher identity is scrutinised as a part of teachers' historical bodies because their background and choices effect on their teaching practices. In other words, teachers' historical bodies are constructed of teacher identity, training, and experiences in and out of school. Scollon and Scollon (2004) deployed the concept of historical body from Nishida (1958), who described the historical body as referring to the idea of a person's past, present, and future life experiences reflecting and contradicting one another. This means that different people act differently in the same situation based on their history of personal experience (Scollon and Scollon, 2004). Scollon and de Saint-Georges (2013) defined the historical body as the social actor's combined social practices and experiences. Therefore, teachers bring their historical bodies into the social action of the classroom; that is, they bring their own skills, experiences, affordances, and constraints (Blommaert and Huang, 2009). The historical body is dynamic and unstable because individuals actively create and develop new social practices within social action and with the environments in which they operate (Larsen and Raudaskoski, 2020). Nishida (1958) stated that individuals are "in the 
transitory movement from being a formed individual towards becoming a forming individual" (p. 168).

In educational research, teachers' historical bodies have been studied among language student teachers (e.g. Kuure et al., 2016), emphasising the participants' experiences and accumulated practices. Teachers' historical bodies in online environments have also been of interest in several nexus analytic studies on online social practices (e.g. Dooly, 2017). These studies considered teachers' accumulated learnerteacher experiences, life histories, and digital technology usage, which they bring into the social action. Teachers' historical bodies have also been analysed in the context of literacy learning (Wohlwend, 2009), information literacy (Hirvonen and PalmgrenNeuvonen, 2019), critical thinking (Nygård et al., 2020), and bilingual education (Dressler, 2018). These relevant studies, together with the current study, highlighted the teacher's role and teaching practices in the classroom. Christensson (2019) found that the presence of historical bodies affects the circulating discourses in social action. Based on these studies, the concept of the historical body enables the co-construction of situational identity within social action (Norris, 2008): the teacher identity is embedded in and intertwined with the teacher's historical body (Norris, 2011).

\section{Method}

Data for this study were collected through interviews with eight secondary school health education teachers in Finland between November 2019 and January 2020. The length of the interviews ranged from 56 to 80 minutes. Snowball sampling (Goodman, 1961) was used to recruit interviewees: each interviewee was asked to name one or more health education teachers who might be interested in taking part in the study. Recruitment continued in this manner until no further interviews were needed, that is, when data 
saturation was achieved. Three male and five female teachers participated in the study. The participants' teaching experience and educational backgrounds varied (see Table I). All teachers had a master's degree, which is a common educational background for Finnish teachers. In addition, one teacher had completed a licentiate degree and one teacher had doctoral studies in progress. Further, two teachers had previous training and work experience in the health sector. All names were pseudonymised.

Only one teacher had health education as her primary teaching subject. She also worked as a student counsellor. The other teachers' primary teaching subjects were physical education, home economics, biology and geography, and history and social studies. One teacher was a primary school teacher, but he also taught health education for grades 7 to 9 . Six teachers had completed health education teacher qualification studies, one was in the midst of completing their studies and one teacher was without qualifications.

Table I. Teachers' educational background and teaching experience.

To explore teachers' perceptions and views of their teacher identity and to reflect their education, teaching experience, and teaching subjects in terms of that professional identity, unstructured, narrative interviews were chosen as the data collection method (Hua, 2016). The theme highlighted in the interviews was teachers' ways of promoting students' critical thinking and information-seeking and evaluation skills from the perspective of the teachers' historical bodies and teacher identities. The interview themes were broadly decided in advance, but the structure was otherwise kept open, allowing each interview to develop individually and situationally (Hua, 2016). The narrative interviews were conducted avoiding precise "how" or "what" questions, but instead, the participants were asked to tell or reflect on topics, such 
as, "tell me about your teacher path". At the same time, the narrative interviews were bounded by the research questions in order to define research interests (Josselson, 2013).

The analytical lens of this study is historical body as a key element of social action (see 1.3) within nexus analysis (Scollon and Scollon 2004). In the analysis, the focus was on the teachers' historical bodies, which were considered to be an entity comprising teacher identity, training, and experiences. Moreover, the analysis of the teachers' historical bodies was based on the participants' own narratives, and thus, the main mediational mean was language. Although nexus analysis considers all situated mediational means (Scollon and de Saint-Georges, 2013), the teachers' teacher identities were primarily explored based on their statements. The connection between what the teachers said (informing) and did (action) and their being (identity) was of interest in this study as it allowed us to understand what they aimed to do and whom they wanted to be by describing their teaching (Gee, 2005).

\section{Results}

According to the analysis, the teachers described their teacher identity in terms of 1) embodying their profession: Teachers as "doers" 2) subject content: Teachers as content specialists, and 3) trust: Teachers as relationship builders. In the first two categories, two teachers were placed in each, and in the third category, four teachers. In the following sections, these different ways of constructing teacher identity are analysed. The way in which these teacher identities are manifested in teachers' ways of teaching information-seeking, information evaluation, and critical thinking skills to students, is also explored. 
Two teachers, Annie and Rick, with very different educational background constructed their identity through their personal interest in physical activities, exercising, and doing. Annie, the physical education teacher, stressed that "My professional identity and outside-of-school identity do not differ strongly. I mean, physical activity and health [have] always been important to me, and it is an extremely significant part of me". Annie considered herself to be a bodily person whose historical body was based on the background of being a ballet dancer and participating in women's voluntary military service. After graduating from high school, becoming a physical and health education teacher was not Annie's priority for professional aspiration, in fact, she never thought she would strive for the teaching occupation. However, she had no doubts as to the suitability of her career choice. As she said in her interview, "It's strongly me, and now I get to do the job that I am". She viewed that she was the embodiment of her own work; her work expressed her historical body: "I perceive myself totally as ... a role model of physical, mental, social wellbeing at school. And it is kind of genuine and endogenous".

Rick sought to explain his teacher identity through the trajectories of his former and current occupations. He worked earlier as a trained physiotherapist, but he had had to change professions for health reasons. He noted in his interview that

\footnotetext{
Nowadays I am more and more a teacher, but of course, I can't get rid of that physiotherapy either, and I don't want to get rid of it. It has probably contributed to my point of view or my way of thinking.
}

Rick first studied to be a primary teacher, and, after some years of working, he continued with his health education teacher qualification studies. He said that these 
studies were a kind of connective factor between his former and the current profession, and thus, completing the qualification was adequate.

Rick described himself as a person for whom physical activity played an important role in life. According to Rick, his penchant for sports and exercise influenced his attitudes towards the health education: "Well yes, mainly, of course, because it is my favourite subject this exercising thing, so maybe it could be that I look at it [health education] through those glasses a little more then". Being a physiotherapist was part of Rick's historical body and had helped construct his teacher identity. He named it as one of the cornerstones. However, with age, Rick had come to realise the importance of teachers' educational work and students' wellbeing at school. He described this transformation of the teacher identity: "In the teacher's job, there is a part, is it an educational side ... maybe more with age, I have started to notice ways one could bring a good atmosphere to these juniors and meaningfulness for the schoolwork". Rick's case illustrates how, like his historical body, teacher identity is constantly in a state of both conscious and subconscious change.

Challenges related to teaching information-seeking and evaluation skills were mainly based on the modern media environment, that is, the Internet and social media, and the rapidly growing amount of health information. Annie stated that

\begin{abstract}
All kinds of information bursts from thousands of places. In a way, to learn to question, what is information, like factual information. What is just provocation. What is worth believing. The amount of information concerning health, exercise, standard of beauty, sportiness, wellbeing, especially nowadays, it's a shocking amount of information out there. To learn to know what information we need, what we can utilise.
\end{abstract}


Annie viewed it was crucial for students to learn how to assess information credibility. Thus, her role as a teacher was to "Introduce information sources to them. I teach them to use the right channels". For Annie, it was obvious that students could not learn information evaluation and critical thinking skills by themselves. It was her duty to question and doubt and to teach students to doubt, to think critically, and to ask.

Both health education and physical education are subjects in which teachers are "on display" (Annie), meaning the teacher is positioned in front of the students, both figuratively and literally. In addition, the content taught can be intimate. To enable learning, teachers must present themselves as trustworthy and approachable people. Thus, students know that "In this class, when the door closes, you are allowed to ask" (Annie). According to Annie, teachers' substance knowledge was important, but the most essential tool was their own personality.

Annie and Rick constructed their teacher identity through a combination of activity, healthy lifestyles and doing. This functional approach was also seen in their ways of teaching critical thinking and information evaluation. Rick emphasised varied teaching styles and learning methods, including group works, learning games and videos, and learning by doing. So far, the selection of health information had been teacher-led, and Rick emphasised common sense being important: "There are all sorts of trends in these health issues, and maybe it's not quite worth going for any new recommendations in full ... so, realism in health-related issues and how they are handled". However, he had noticed that teachers' role in teaching information-seeking and evaluation was changing:

The present trend is that kids should increasingly discover it [information] themselves, but, of course, it is significant if someone directs towards information, tries to divide that information into comprehensible pieces ... And 
if even the great and mighty teacher does not know everything, you know where to find that additional, relevant information. And when seeking information, critically evaluate whether that information is smart or not.

Rick accentuated the significance of relevant, rational information and common sense, which support choices in everyday life.

\subsection{Teachers as content specialists}

Two teachers, Nancy and Lenny, clearly constructed their teacher identity based on the subjects they taught. However, in the interviews, it was difficult to distinguish a person's teacher identity from their overall identity. Nancy pondered her teacher identity: “I don't know if I've actually thought about it. It is part of my identity, professional identity is part of a person's identity, yes, my identity is that of a teacher". Nancy had been working as a subject teacher at the secondary and upper secondary level for almost 20 years, and as a qualified health education teacher for 10 years. Geography was her first choice, but she later gravitated toward health education for practical reasons: "At that time, it was probably because I didn't have a permanent post, so it gave an additional opportunity to apply for jobs". According to Nancy, being a qualified of a health education teacher alongside biology and geography is an advantage in a job search.

As a doctoral researcher, Nancy had a strong scientific interest in her teaching subjects and teaching. She enjoyed teaching health education as a part of a three-subject triangle - biology, geography, and health education — because it enabled her to carry out teaching as phenomenon-based learning. That was possible because she taught the same student groups in all three subjects and could, therefore, tailor her lessons around 
the same phenomenon theme, but from various perspectives. For Nancy, her own teaching subjects gave her work meaning. She pointed out that

Well, in a way ... that I have the privilege of doing this work, I never have to think whether my job has significance. Indeed, I draw from geography, biology, and health education the relevance of the work from the contents of what I teach.

Lenny also constructed his teacher identity based on his teaching subjects. He said in his interview that "Maybe my identity comes more, however, from the point of view of biology and geography ... in a way, that health education feels kind of being a bit detached". His interest in the natural sciences and nature-related hobbies, such as fishing and hunting, was the initial reasons he studied geography as a main subject. He graduated as a teacher three years ago, and since then, he had been teaching geography, biology and health education for which he is qualified. He explained his choice of subjects by saying, "Perhaps it was my first idea to study biology, geography, and my focus was in these disciplines. But when I thought about the school world ... health education nowadays kind of belongs closely to the biology-geography teacher's package".

Like Nancy, Lenny obtained his qualification in health education for practical reasons, considering future work assignments. However, Lenny had also reflected on other reasons to study health education:

When thinking about human biology, what is taught and then health education, it is important to understand both sides ... yes, they are so tightly interrelated that I thought it begins to be self-evident to study health education in support of this. 
The content of biology and health education overlap, which enables a broader, phenomenon-based perspective of the different themes. Both teachers noticed this advantage and sought to utilise it in their teaching.

The teachers highlighted the significance of seeking and evaluating the credibility of health information as learning goals of health education. Nancy noted that health information is increasingly sought on the Internet:

Google searches related to health and illness are the most common [searches] of all ... so, critical media literacy is absolutely essential. And then, the students are keen on being specifically guided towards credible information sources ... and in everyday life making sensible choices to promote their own and community's health.

According to Nancy, students relied on her abilities to guide them towards credible information sources and expected her to do so. Explaining her method of conveying scientific knowledge, Nancy said that "The absolute truth is probably not even found on many topics. Then you just have to point out that this is the current scientific understanding [of] the subject".

Secondary school students need their teacher's help to learn how to evaluate information because

Students in the upper secondary school have clearly better transferable skills. Secondary school students have more of that the first Google hit is the one from which the text is copied and pasted ... this happens a lot more with secondary school students.

Nancy viewed teachers as able to make an impact and teach information-seeking and evaluating skills to the young people because their skills in this area had proved to be 
deficient. In grade 7, students' ability to seek and evaluate credible health information was still undeveloped, but by the end of secondary school, most of them had advanced in these areas.

Lenny based his teacher identity on subject content and knowledge. This was evident in his views on teaching information-seeking and evaluation. He named the most important learning goal in health education as being "Precisely this critical thinking ... because today, it is needed more and more. The power of social media is growing unrestrainedly all the time, everyone goes to social media, everything is on the net, so yes, it is needed". His professional role model was his former teacher, who gained a position of authority through his knowledge. Lenny's aim was the same, that is, gaining the authority role by knowing and especially through being a trustee. He said that

The teacher is, if necessary, the databank, but on the other hand, I have tried to think and get rid of it in the sense that if the teacher is always that databank, who always gives the answer, so then as if to guide the students to seek information and discuss, where to look for that information. That is, without giving all then ready.

In Lenny's case, students easily resorted to posing questions to the teacher, especially, if they were then provided with the correct answers without their own effort. Lenny had noticed that students appreciated his special knowledge, for instance, the scientific names of animals, which encourage students to ask him questions and, in addition, trust him as a teacher because "the information has been accurate". 


\subsection{Teachers as relationship builders}

Among the participants, most common teacher identities were grounded in interpersonal relationships in the classroom. Karen, Laura, Julia, and Matthew saw that their teacher identities were primarily built through everyday interaction. Teachers with a longer work history were able to verbalise their teacher identity more fluently. Karen had worked as a nurse for a long time before studying to become a qualified vocational teacher. She taught nursing and, at the same time, studied health sciences at the university. When health education became a mandatory subject in 2004, she was asked to teach it at her current school. Later she completed the health education teacher qualification alongside the job. Her historical body was based on her extensive educational background and work experience setting the tone for her teacher identity, which had formed

In a bit of searching, or I have had to take an effort for it ... I think it builds gradually; it doesn't change in an instant ... I remember during my first years, my nurse identity was pretty dominant, and I strove to nurse students back then also.

Karen's professional identity had gradually transformed from a nurse identity to a teacher identity in which "The educational side, especially now in recent years, it feels like this educational grasp, because students have a huge need for adult presence. In other words, being an adult to them". Despite her strong content knowledge, she valued her role as a safe and responsible adult for the students.

In contrast, Laura had a shorter work history as a teacher. She had graduated as a home economics teacher a year before the present study was conducted, and she had also completed her health education teacher qualification during these studies. As a 
recent graduate teacher, she had given much thought to her teacher identity and had approached it through her strengths and weaknesses: "I feel that I have strengths as a teacher, and, in a way, it supports the growth of my teacher identity". At the same time, she felt uncertain about her resilience, because a teacher's work can occasionally become onerous. Also, students' life situations and difficulties made her ponder:

Students have a variety of problems, often due to their family background, and it feels bad to be a bystander. When you see that in a way, they are going in the wrong direction and you have really limited possibilities to help when you see them one hour once a week. Somehow the fact that how to cope when so many students are doing badly.

As an empathetic and kind person, Laura would have liked to be able to help more than she was actually able to. This aroused powerlessness and perplexity in her, but also a sense of the importance of her work. Laura's teacher identity had not yet been established, but she was beginning to construct it.

Julia graduated six years ago and had worked as a substitute teacher ever since, of which for two years as a full-time subject teacher. Her main teaching subjects were geography and biology, and she was completing her health education teacher qualification studies at the time of this study. The decision to complete this qualification was based on the opportunity to teach health education at her current school. Of teacher identity, she viewed that

It probably evolves during the career ... yes, it will emerge gradually. And without it you can't cope. Somehow, I think everyone has a teacher identity of their own kind. It will emerge, it develops over the years, but it exists already from the beginning. 
Julia perceived that the construction of a teacher identity starts at the very beginning and continues throughout a teacher's career. At the time of her interview, Julia had been working as a teacher for several years, and was, therefore, able to analyse her teacher identity. She emphasised "Being a role model ... really in everything, whatever we talk and whatever subject. If we talk about health education, lifestyles and on the other hand, behaviour and emotional skills and consideration for others and so forth". Julia viewed her teacher identity as being intertwined with a teacher's position as a role model for students. She stressed that, in the working environment, she is above all a teacher, even when she is tired: "As soon as you step into the workplace or that area there, that teacher identity and role come on and you greet and so on". For her, teacher identity was based on constructing relationships with her students and could be maintained through interaction.

Matthew differed from the other interviewees in that he was not a qualified health education teacher, and, at the time of the interview, he had no intention of completing the qualification. This was because he was a history and social studies teacher, and if he were to apply for permanent posts, health education would not fall within a history teacher's package. Matthew graduated five years ago and had since taught history, social studies, religion, ethics, and health education at the secondary and upper secondary level. In addition, he had worked as a supervising teacher for student teachers. Because he was involved in constructing their teacher identities, he viewed that he already had to have a pretty solid teacher identity. Matthew explained his teacher identity:

I have noticed that this [teaching] works well for me, and basically, it's kind of interpersonal work and encountering people. I feel that it is natural for me. 
Maybe the content knowledge is not my number one concern here, or why I am a teacher. But it just focuses on human encounter.

For him, teaching was primarily about working with people. His teacher identity was constructed through interaction, not based on teaching subjects.

Matthew emphasised secondary school teachers' opportunities to teach students how to approach information sources in all subjects critically. He stated that "We can teach it a lot, just this sort of source criticism and media literacy comes forth more or less in all subjects. At least in my teaching”. In his main subjects, history and social studies, he had taught source criticism but had not yet taught it in health education. The interview brought forth tension in this matter, and thus, Matthew stated that he intended to change his actions in this regard in the future: "In health education, I haven't paid so much attention to it, partly because lack of time, but maybe inspired by this [interview] then even more. I could discuss it".

Although Karen had a strong working experience both in nursing and teaching, she found assessing the credibility of contemporary health information to be difficult and confusing. She said in the interview that she sometimes could not tell what to think about health recommendations concerning cholesterol, for instance. It can be challenging to determine what to believe and whom to trust in these recommendations. Karen had taught her students how to ponder the information credibility by advising them that "Manifold information is available; you just have to somehow find the correct one. So, I have no answers to that what is exactly the right information either".

In her teaching, Karen emphasised the significance of joint discussions and viewed that effective teaching methods were "Just exploring different kinds of sources and guiding to use them and discussing those sources". Karen's teacher identity was 
built and maintained through classroom interaction. Thus, it was natural for her to evaluate credible sources as part of the learning community. However, the restrictions of the school schedule affected the content of the lessons. Karen said, "I wish that we had more time for discussions, which are occasionally left out, especially, because one lesson is only 45 minutes".

Julia also wished she had more time or at least double lessons instead of having "45 minutes once a week, it's terribly inadequate in order to discuss all these questions". She said that this presented a challenge in teaching health education because she would like to be able to teach more thoroughly, using varied teaching methods, and focus on the use of credible information: "all blogs and more, I didn't grasp to take them as an example of how important [it] is to know who is behind the stories. Many may even consider themselves as experts, after reading on the net sufficiently information". Julia pointed out that information environments had changed over the past few years so that health authorities and informal Internet sources were now considered to be on the same footing when selecting information. This change meant that teachers now played an even more important role in helping students to develop the skills to seek and assess information credibility.

It plays an important role, because if you don't have these skills, you are not critical enough and can't seek information. You might just take as a fact the first webpage or anything that comes up in social media without realising that many issues have many sides. And just these experts by experience and others then. It [skills to evaluate information] really plays an important role. And then to learn to seek information from credible sources.

During her first five months of teaching, Laura had noticed that secondary school students had weak information-seeking and evaluation skills. However, she 
viewed that this was mainly due to the huge amount of information available. In her opinion, the students did not care to focus on seeking credible information but rather took the first title without comparing different information sources. Laura found that teachers acted as gatekeepers, because "The teacher selects what to go through there ... from where we study those things and then what is used as additional material for it". This role is further emphasised when learning material other than a health education textbook is used because teachers determine all the information that the lesson offers. In addition, teachers filter and limit the information and also guide students towards credible information sources. Laura noted that when they jointly discussed health related advertisements on the lessons,

Lack of critical thinking is clearly quite prevalent among students ... they may not realise that these are mere advertising slogans, intended to evoke the need to some product ... [it] requires practice and repetition, systemically process different kinds of texts.

Laura believed students developed competencies through joint discussions and reflection, as well as with the teacher's guidance.

\section{Discussion}

This study focused on teachers' professional identities in relation to teaching information-seeking and critical evaluation skills. In the interviews, the teachers were given an opportunity to reflect on their teacher identity and narrate it to the researcher as they viewed it at the time. The analysis indicated that the teacher identities were constructed along different paths, but their goal was the same: interact with their students as a trusted adult. The teachers viewed that trust did not arise by itself, but through doing, knowing, and being in the interaction with students. The relationships 
between students and teachers played an important role in this trust process, and teachers' strong content knowledge laid the foundation for a trustworthy relationship (Nygård et al., 2020; Tschannen-Moran and Hoy, 2000). According to Beijaard and Meijer (2017), these interacting personal and professional factors have an impact on teacher identities and teachers' ways of teaching information evaluation and critical thinking, for instance.

Annie and Rick, whom we defined as active "doers" and bodily oriented, emphasised common sense and the practical side of information-seeking skills. They brought up the fact that students are not able to attain these skills-information-seeking, credibility evaluation, and critical thinking - by themselves, but they need to be taught. Besides teaching all the skills, teachers act as role models and, through their actions, show how to question, doubt, and choose health information. The teachers noted that attention should be paid to seeking and evaluating credible information in each task, which, however, has not always been the case. Although the current curriculum (Finnish National Board of Education, 2016) increases students' responsibility to self-direct in information-seeking and evaluation situations, the teachers are still significant information sources and the ones who guide students towards credible information sources (Nygård et al., 2020). Similar to our previous research, teachers' credibility as trustees depended on their relationships with their students, and, more importantly, awareness of the trustful interaction during health education lessons (Jessen and Jørgensen, 2012).

Nancy and Lenny, who considered content knowledge to be a key factor in the construction of teacher identity highlighted their position as trustees and informational authorities (Nygård et al., 2020). The trustee position was, above all, based on information. A trusting relationship was the result of repeatedly given correct information. The teachers noticed that secondary school students, in particular, needed their teacher's support in seeking and evaluating health information. 
Thus, they specifically relied on the teacher's guidance and advice. The teachers themselves leaned on scientific knowledge and wanted to teach this same attitude towards information to their students. Their teacher identity was based on subject expertise and pedagogical knowledge and was constantly performed and transformed in the classroom through interaction with students (Bukor, 2015; Day, 2012; Jourdan et al., 2016; Miller, 2009).

Teachers Matthew, Karen, Julia and Laura constructed their teacher identity through interactions with their students. As teachers, they found genuine encounters with students and filling their students' needs to be important (Puchegger, 2018). Some of the teachers admitted that information-seeking today is a challenging task for the teacher as well as the students. Health recommendations may confuse even health professionals, and teachers do not always have the correct answers. The teachers expressed that an important means of evaluating information was joint classroom discussions, which the teacher was able to take part in equally. Collaborative meaningmaking and knowledge construction were also highlighted as an important teaching method in assessing the credibility of health information despite insufficient time resources. Teachers' roles were seen diverse, serving as a knowledge co-constructor, a gatekeeper, and a trustee at the same time. This finding coincides with that of our earlier study, which found that teachers are informational authorities (Nygård et al., 2020). The teacher's role was significant because the lack of source criticality led the students to resort to the teacher for guidance (Heinström and Sormunen, 2019).

According to the results, teachers' ways of teaching information-seeking, evaluation, and critical thinking skills, and how important they considered teaching those skills to be in health education, were based on the teachers' historical bodies. The 
historical body combines an individual's social practices and life experiences (Scollon and de Saint-Georges, 2013), which feeds teacher's professional perception of themselves, that is, their teacher identity (Blommaert, 2005; Mockler, 2011). Therefore, a teacher's skills and interests, information-seeking habits, and familiar sources affect how they teach and guide students (see Hirvonen and Palmgren-Neuvonen, 2019; Blommaert and Huang, 2009; Dressler, 2018). It can even be said that teachers are not necessarily aware of incorrect, even dangerous, health information if they do not actively seek it.

The results of the study were based on only one round of interviews; hence, it would have been advisable to monitor changes in teacher identities with follow-up interviews. However, teacher identity was scrutinised through the concept of historical body, which could be considered as a repository of past, present, and future experiences. Thus, each historically loaded social action could be seen as a socially and culturally mediated moment (Blommaert and Huang, 2009).

\section{Conclusions}

The study discussed how teacher identity is formed through teacher training and work experience, as well as through interaction and verbalization of the phenomenon. The interviews prompted the teachers to reflect on their ways of teaching informationseeking, evaluation, and critical thinking skills, causing tension between their accustomed practices and desirable learning outcomes. Thus, the interviews served not just as a repetition of reality, but as a reconstruction of it in terms of teacher identity. This finding suggests that a research approach can be utilised to produce and develop identity.

Health information environments today are complex and erratic. Therefore, new kinds of literacy skills — such as information seeking and evaluation as part of 
multiliteracy — are needed. Schools and teachers must respond to the prevailing situation and be prepared to adjust their accustomed practices as the situation changes. Teachers have an important role to play in teaching information credibility assessment, because parents' competences in this matter are of very different levels.

This study highlights the need to reconsider ways of learning and teaching information-seeking and evaluation skills in health education. Health education is in a challenging position, because most of the teachers teach it as their second teaching subject. The central question is how to motivate teachers to enhance their skills as a health education teacher, when their primary interests are perhaps the first chosen teaching subjects. The findings of this study on teacher's historical body as one of the cornerstones of teacher identity can help teachers reflect their identity in teaching health education in particular. Collegial collaboration among teachers could contribute to this reflection and even increase the perceived value of the subject. New research on a virtual teacher network is currently underway; in this virtual network, health education teachers will have the opportunity to develop their skills in a peer group. The purpose is that teachers with their varied historical bodies will be allowed to join in collaborative brainstorming and knowledge construction in order to develop ways of teaching information-seeking and critical evaluation.

\section{Acknowledgements}

The study was funded by the Academy of Finland (Grant No. 299112) and Jenny and Antti Wihuri Foundation.

\section{Disclosure Statement}

No potential conflict of interest was reported by the authors.

\section{References}

Anspal, T., Leijen, Ä., and Löfström, E. (2019), "Tensions and the teacher's role in student teacher identity development in primary and subject teacher curricula", Scandinavian Journal of Educational Research, Vol 63 No. 5, pp. 679-695. 
doi: $10.1080 / 00313831.2017 .1420688$

Ball, S.J. and Goodson, I.F. (1985), "Understanding teachers: Concepts and contexts", Ball, S. J. and Goodson, I. F. (Eds.), Teachers' lives and careers, Falmer Press, London, pp. 1-26.

Beauchamp, C. and Thomas, L. (2009), "Understanding teacher identity: An overview of issues in the literature and implications for teacher education", Cambridge journal of education, Vol 39 No 2, pp. 175-189. doi:

$10.1080 / 03057640902902252$

Beijaard, D. and Meijer, P.C. (2017), "Developing the personal and professional in making a teacher identity", Clandinin, D. J. and Husu, J. (Eds.), The SAGE Handbook of Research on Teacher Education, SAGE Publications Ltd, London.

Blommaert, J. (2005), Discourse: A critical introduction, Cambridge University Press, Cambridge.

Blommaert, J. and Huang, A. (2009), "Historical bodies and historical space", Journal of Applied Linguistics-London, Vol 6 No 3, pp. 267-282. doi:

10.1558/japl.v6i3.267

Bukor, E. (2015), "Exploring teacher identity from a holistic perspective:

Reconstructing and reconnecting personal and professional selves", Teachers and teaching, Vol 21 No 3, pp. 305-327. doi: 10.1080/13540602.2014.953818

Byrne, J., Rietdijk, W. and Pickett, K. (2018), "Teachers as health promoters: Factors that influence early career teachers to engage with health and wellbeing education", Teaching and Teacher Education, Vol 69, pp. 289-299. doi: 10.1016/j.tate.2017.10.020 
Christensson, J. (2019), "This is where my inner history teacher appears': a methodological approach to analysing student teachers' professional identity in interaction", Classroom Discourse, Vol 10 No 2, pp. 168-187.

doi: $10.1080 / 19463014.2018 .1530685$

Day, C. (2012), "New Lives of Teachers", Teacher Education Quarterly (Claremont, Calif.), Vol 39 No 1, pp. 7-26. available at: https://www.jstor.org/stable/23479560

Dooly, M. (2017), "A Mediated Discourse Analysis (MDA) approach to multimodal data", Moore, E. and Dooly, M. (Eds), Qualitative approaches to research on plurilingual education, Research-publishing.net, pp. 189-211.

doi: $10.14705 /$ rpnet.2017.emmd2016.628

Dressler, R. (2018), "Canadian bilingual program teachers' understanding of immersion pedagogy: A nexus analysis of an early years classroom", Canadian Modern Language Review, Vol 74 No 1, pp. 176-A-8. doi: 10.3138/cmlr.3407

Finnish National Board of Education. (2016), National core curriculum for basic education 2014, Finnish National Board of Education, Helsinki.

Gee, J. P. (2000), "Chapter 3: Identity as an analytic lens for research in education", Review of research in education, Vol 25 No 1, pp. 99-125.

doi: $10.3102 / 0091732 \times 025001099$

Gee, J. (2005), An Introduction to Discourse Analysis, Routledge, London. doi: $10.4324 / 9780203005675$ 
Goodman, L. A. (1961), "Snowball sampling", The annals of mathematical statistics, Vol 32 No 1, pp. 148-170. doi:10.1214/aoms/1177705148

Heinström, J. and Sormunen, E. (2019), "Structure to the unstructured - Guided Inquiry Design as a pedagogical practice for teaching inquiry and information literacy skills", in Proceedings of ISIC, The Information Behaviour Conference, Krakow, Poland, 9-11 October: Part 2. Information Research, Vol 24 No 1, paper isic1824.

Hirvonen, N. and Palmgren-Neuvonen, L. (2019), "Cognitive authorities in health education classrooms: a nexus analysis on group-based learning tasks", Library and Information Science Research, Vol. 41 No 3, doi: 10.1016/j.lisr.2019.100964.

Hua, Z. (2016), Research methods in intercultural communication: A practical guide, Wiley Blackwell, Chichester, West Sussex.

Jessen, J. and Jørgensen, A.H. (2012), "Aggregated trustworthiness: Redefining online credibility through social validation", First Monday, Vol 17 No 1. doi: $10.5210 / \mathrm{fm} . v 17 \mathrm{i} 1.3731$

Jones, R. H. and Norris, S. (2005), "Discourse as action/discourse in action", Norris, S. \& Jones, R. H. (Eds.), Discourse in Action, Routledge, London, pp. 15-26.

Josselson, R. (2013), Interviewing for qualitative inquiry: A relational approach, Guilford Press, New York.

Jourdan, D., Simar, C., Deasy, C., Carvalho, G. S and McNamara, P. M. (2016), "School health promotion and teacher professional identity", Health Education, Vol 116 No 2, pp. 106-122. doi: 10.1108/HE-07-2014-0078

Kannas, L., Peltonen, H. and Aira, T. (2009), Terveystiedon kehittämistutkimus: Osa I, Kokemuksia ja näkemyksiä terveystiedon opetuksesta yläkouluissa, Jyväskylän yliopisto, Opetushallitus, [Jyväskylä], Helsinki. 
Kuure, L., Molin-Juustila, T., Keisanen, T., Riekki, M., Iivari, N. and Kinnula, M. (2016), "Switching perspectives: from a language teacher to a designer of language learning with new technologies", Computer Assisted Language Learning, Vol 29 No 5, pp. 925-941. doi: 10.1080/09588221.2015.1068815

Larsen, M. C. (2007), "Understanding social networking: On young people’s construction and co-construction of identity online", Internet Research, Vol 8, pp. 18-36.

Larsen, M. C. and Raudaskoski, P. (2020), "Nexus Analysis as a Framework for Internet Studies", Hunsinger, J., Klastrup, L. and Allen, M. (Eds), Second International Handbook of Internet Research, Vol 2, Springer, Dordrecht, pp. 815-834. doi:10.1007/978-94-024-1202-4_18-1

Lutovac, S. and Kaasila, R. (2019), "Methodological landscape in research on teacher identity in mathematics education: A review", ZDM, Vol 51 No 3, pp. 505-515. doi: $10.1007 / \mathrm{s} 11858-018-1009-2$

Mannix McNamara, P., Moynihan, S., Jourdan, D. and Lynch, R. (2012), "Pre-Service Teachers' Experience of and Attitudes to Teaching SPHE in Ireland", Health Education, Vol 112 No 3, pp. 199-216. doi: 10.1108/09654281211217759

McDougall, J. (2010), "A crisis of professional identity: How primary teachers are coming to terms with changing views of literacy", Teaching and Teacher Education, Vol 26 No 3, pp. 679-687. doi: 10.1016/j.tate.2009.10.003

Miller, J. (2009), "Teacher identity", Burns, A. and Richards, J. C. (Eds.), The Cambridge guide to second language teacher education, Cambridge University Press, New York, pp.172-181. 
Mockler, N. (2011), "Beyond 'what works': Understanding teacher identity as a practical and political tool", Teachers and Teaching, Vol 17 No 5, pp. 517-528. doi: $10.1080 / 13540602.2011 .602059$

Nishida, K. (1958), Intelligibility and the philosophy of nothingness, Greenwood Press, Westport, Connecticut.

Norris, S. (2004). Analyzing multimodal interaction: A methodological framework, Taylor \& Francis Group, London.

Norris, S. (2008), "Some thoughts on personal identity construction. A multimodal perspective", Bhatia, V., Flowerdew, J. and Jones, R. H. (Eds.), Advances in discourse studies, Routledge, London, pp. 130 - 148.

Norris, S. (2011), Identity in (inter) action: Introducing multimodal (inter) action analysis, De Gruyter Mouton, Berlin.

Nygård, T., Hirvonen, N., Räisänen, S. and Korkeamäki, R.L. (2020), “Ask your mother! Teachers' informational authority roles in information-seeking and evaluation tasks in health education lessons", Scandinavian Journal of Educational Research, pp. 1-14, doi: 10.1080/00313831.2020. 1788145 .

Ormshaw, M. J., Paakkari, L. T. and Kannas, L. K. (2013), "Measuring child and adolescent health literacy: a systematic review of literature", Health Education, Vol 113 No 5, pp. 433-455. doi: 10.1108/HE-07-2012-0039

Palmér, H. (2016), "Professional primary school teacher identity development: a pursuit in line with an unexpressed image", Teacher Development, Vol 20 No 5, pp. 682-700. doi: 10.1080/13664530.2016.1202311

Pang, B. and Soong, H. (2016), "Teachers' experiences in teaching Chinese Australian students in health and physical education", Teaching and Teacher Education, Vol 56, pp. 84-93. doi: 10.1016/j.tate.2016.01.023

Puchegger, R. (2018), The complexity of becoming HPE teacher: A study of HPE teachers' performances of self in the moments of teaching, doctoral dissertation, 
ResearchSpace@Auckland, available at:

https://researchspace.auckland.ac.nz/handle/2292/37342

Räisänen, S. and Korkeamäki, R.L. (2015), “Implementing the Finnish literacy curriculum in a first-grade classroom", Classroom Discourse, Vol. 6 No. 2, pp. 143-157, doi: 10.1080/19463014.2015.1036900.

Scollon, R. (2001), "Action and text. Toward an integrated understanding of the place of text in social (inter)action", Wodak, R. and Meyer, M. (Eds.), Methods in Critical Discourse Analysis, Sage, London, pp. 139 - 183.

Scollon, S. W. and de Saint-Georges, I. (2013), "Mediated discourse analysis", Gee, J. and Handford, M. (Eds.), The Routledge handbook of discourse analysis, Routledge, London, pp. 92-104.

Scollon, R. and Scollon, S.W. (2004), Nexus analysis. Discourse and the emerging internet, Routledge, London.

Sikes, P. (1985), "The life cycle of the teacher", Ball, S. J. and Goodson, I. F. (Eds.), Teachers' lives and careers, Falmer Press, London, pp. 27-60.

Sirna, K., Tinning, R. and Rossi, T. (2010), "Social processes of health and physical education teachers' identity formation: Reproducing and changing culture", British Journal of Sociology of Education, Vol 31 No 1, pp. 71-84.

doi: $10.1080 / 01425690903385501$

Tinning, R. (2004), "Rethinking the preparation of HPE teachers: Ruminations on knowledge, identity, and ways of thinking", Asia-Pacific Journal of Teacher Education, Vol 32 No 3, pp. 241-253. doi: 10.1080/1359866042000295406

Tschannen-Moran, M. and Hoy, W. K. (2000), "A multidisciplinary analysis of the nature, meaning, and measurement of trust", Review of educational research, Vol 70 No 4, pp. 547-593. doi: 10.3102/00346543070004547 
Wertsch, J. V. (1994), "The primacy of mediated action in sociocultural studies", Mind, Culture and Activity, Vol 1 No 4, pp. 202-208. doi:

$10.1080 / 10749039409524672$

Wohlwend, K. (2009), "Squeezed, stretched, and stuck: Teachers defending play-based learning in no-nonsense times", Boldt, G. M., Salvio, P. M. and Taubman, P. (Eds.), Classroom life in the age of accountability: Bank Street College Occasional Papers Series (Vol. 22), Bank Street College, New York, pp. 8-16. 
Table I. Teachers' educational background and teaching experience.

\begin{tabular}{|c|c|c|c|c|}
\hline Teacher & Subjects & $\begin{array}{c}\text { Teaching } \\
\text { Years }\end{array}$ & $\begin{array}{c}\text { Former } \\
\text { Profession }\end{array}$ & Further Studies \\
\hline Annie & $\begin{array}{l}\text { Physical education } \\
\text { Health education }\end{array}$ & 16 & Primary teacher & Licentiate degree \\
\hline Julia & $\begin{array}{l}\text { Geography } \\
\text { Biology } \\
\text { Health education }\end{array}$ & $\begin{array}{c}6 \\
2 \text { (full-time) }\end{array}$ & - & $\begin{array}{l}\text { Health education studies } \\
\text { in progress }\end{array}$ \\
\hline Karen & $\begin{array}{l}\text { Health education } \\
\text { Student counselling }\end{array}$ & 16 & $\begin{array}{l}\text { Nurse } \\
\text { Vocational teacher }\end{array}$ & - \\
\hline Laura & $\begin{array}{l}\text { Home economics } \\
\text { Health education }\end{array}$ & $<1$ & & $\begin{array}{l}\text { German language } \\
\text { studies in progress }\end{array}$ \\
\hline Lenny & $\begin{array}{l}\text { Geography } \\
\text { Biology } \\
\text { Health education }\end{array}$ & 2 & 一 & - \\
\hline $\begin{array}{l}\text { Matthe } \\
\text { w }\end{array}$ & $\begin{array}{l}\text { History } \\
\text { Social studies } \\
\text { Religion } \\
\text { Ethics }\end{array}$ & 5 & - & $\begin{array}{l}\text { Psychology studies in } \\
\text { progress }\end{array}$ \\
\hline
\end{tabular}


Health education

\begin{tabular}{llll}
\hline Nancy & Geography & 19 & Doctoral studies in \\
& Biology & & progress \\
& Health education & 16 & \\
\hline Rick $\quad$ Primary teacher & & \\
& Health education & & \\
& & \\
\hline Note. Primary teaching subjects are indicated in bold.
\end{tabular}

